Article

\title{
Interreligious Dialogue in Public Service Broadcasting. A Case Study in Catalonia (Spain)
}

\author{
Amparo Huertas Bailén (D) \\ Department of Audiovisual Communication and Advertising, Autonomous University of Barcelona, \\ Plaça Cívica, 08193 Bellaterra, Barcelona, Spain; amparo.huertas@uab.cat
}

Received: 21 June 2020; Accepted: 25 August 2020; Published: 27 August 2020

\begin{abstract}
This text addresses how the media deals with interreligious dialogue based on the case study of the Catalan public television stations. Our theoretical framework revolves around the concept of mediation, which is regarded as a communicative concept that emphasizes the socializing power of the mass media as well as its potential contribution to social cohesion. A quantitative and qualitative analysis is presented of a sample of 41 multi-religious audiovisual pieces broadcast between 2015 and 2018, which were located in the Corporation's on-demand online service. The religious diversity that currently exists in European cities is reflected in the media content. Although it is true that the Catholic religion features in $63 \%$ of the sample, it only becomes the focal point on less than half of the occasions in which it appears. The religious options with more presence are Catholicism in relation to Islam and atheism in relation to Catholicism, but these cases only account for $26.8 \%$ of the sample. Interreligious dialogue appears as the main focus of the discourse in only $14.6 \%$ of the sample and, in general, the tendency towards a Euro-Catholic-centric discourse has been detected.
\end{abstract}

Keywords: interreligious dialogue; public service broadcasting; mediation; journalism; television

\section{Introduction}

This text reflects on the role of the mass media as mediators of values and knowledge in relation to religious beliefs. However, our focus is on one specific aspect of that mediation, namely the way in which the media treats interreligious dialogue and the kind of relationship that the media's discourse gives rise to among religions in audio-visual narratives. We address this aspect based on the case study of the Catalan public television stations, included in the Corporació Catalana de Mitjans Audiovisuals $(\mathrm{CCMA})^{1}$. In Spain, TV3 stands out as the regional television with the best audience levels. According to data from Kantar Media, in 2019 its audience share was 14.6\%, with Galicia's television in second place $(9.3 \%)$ and the Aragonese network in third (8.8\%). In this country, the average consumption of regional television stations during the year 2019 was $8.2 \%$.

Work on related topics has been carried out mainly in the field of education. Most of them are reflections on how to include religious education in states defined as secular. As for the communication sphere, the latest proposals tend to be framed within the field of research into digital religion (Campbell and Evolvi 2020), which is mainly dedicated to exploring in depth its mediatisation, that is to say, the way religious institutions use the digital environment to spread information about their activity (Krüger 2018; Aeschbach and Lüddeckens 2019; Hjarvard 2011; Morgan 2011).

1 The Corporació Catalana de Mitjans Audiovisuals (CCMA) is a public organization that manages the audio-visual media (TV and radio stations) of the Generalitat de Catalunya. With regard to TV stations, TV3 is the most important, and it offers a generalist form of programming. The others are themed channels: Canal 33 is a cultural channel, Canal 3/24 is an all-news channel, and Club Super 3 is geared towards children. 
In other words, any analyses dealing with religious content in the media and the way they construct the social imaginary around religion and their interrelation, as is the case here, constitute an exception at the present time. In addition, the few existing studies have mainly addressed the treatment of Islam. Bayrakli and Hafez (2016) were among the first to warn of the growth of Islamophobic content in the media after the attacks of 11 September 2001. These authors detected a significant expansion of hate speech based on ignorance and negative emotions from that date onwards. Simultaneously, most of the scant content analysis available has focused on the written press, as can be seen, for example, from the studies carried out on the journalistic coverage of the jihadist attacks that occurred in Barcelona in 2017 (Trujillo and Arévalo-Salinas 2019; Díaz-Campo et al. 2018). It is very likely that the dominance of content analysis in the written press, which is much more common than the analysis of audio-visual journalism, is due to the strong influence of linguistics. However, we should not forget a more logistical issue that has to do with the fact that it is much easier to access printed newspapers from documents archived in specialised newspaper libraries than audio-visual material, at least until the advent of the digital age.

Our theoretical framework revolves around the notion of mediation, which is usually regarded as an anthropological concept that emphasizes the constitutive role of the media at the heart of religious practice (Meyer 2012; Morgan 2011). However, specifically in the history of communication, the concept of mediation has been developed from the study of the socializing power of the media as well as its potential contribution to social cohesion through the dissemination of values and knowledge. There is no doubt about the important role of the media in the reproduction and perpetuation processes of culture (Couldry et al. 2007; Huertas-Bailén 2002; Cuesta 2000; Wolton 1999; Blumler 1993; Martín-Barbero 1987).

Our interest in how the media approaches religion emerged after we were able to ascertain that the idea that progress would lead us to a fully secularised society, which spread throughout Europe, has not been fulfilled (Monod 2015). From a philosophical perspective, Trias (1997) points out that, unlike what was foreseen with the unfolding of modernity, religion continues to occupy important areas: religious values continue to be used to interpret society; many forms of social relations continue to be governed by religion; religion has not been confined to the private sphere; and, finally, although there has been an increase in the number of atheists and agnostics, they continue to be a minority. From an anthropological perspective, Briones-Gómez (2018) points out that, in a secularised world, religion persists to the extent that the social practices in which it manifests itself continue to have social, cultural, or individual functions. From a sociological point of view, more than any kind of secularisation process, what characterises cities today is an increase in religious diversity and, therefore, a diminution in the prominence of the predominant religions (Berger 1999).

In Spain, the July 2019 Barometer by the Centro de Investigaciones Sociológicas (CIS), based on a sample of 2952 people, showed that $44.7 \%$ of those surveyed define themselves as non-practising Catholics, while the percentage of practising Catholics remains at a modest $22.7 \%$. The number of non-practising Catholics in Catalonia is close to the Spanish rate $(41.7 \%)$, but at the same time, it must be said that it is the Spanish autonomous community with the lowest percentage of practising Catholics (10.9\%). This data is the type of information that corroborates the ideas of Briones-Gómez (2018). The aforementioned anthropologist thinks that it would be more appropriate to speak of "decatholization" rather than of secularisation in Spain. However, Briones-Gómez (2018) also claims that the decrease in the number of practising Catholics cannot be interpreted as a loss of influence of the Catholic religion in Spain either, as it is still present in such important areas as education, health, and culture and, from a judicial perspective, offending religious feelings still constitutes a crime, despite repeated complaints from lay groups.

Migratory flows, conversions of native people, and the arrival of new spiritualities (whether as a fad, or as a tool for psychological self-help, among others) have increased the number of beliefs that coexist today, especially in the great cities. As regards minority religions, the results of the same CIS study mentioned above show that just over $2 \%$ of those surveyed, both in Spain and Catalonia, claim to 
be believers in religions other than Catholicism. Among the minority religions, the following stand out: Evangelism, but predominated by Pentecostalists; Islam, mainly of the Sunni tradition; Christian Jehovah's Witnesses; and Judaism. This $2 \%$ is mainly based in Madrid and Barcelona, as shown by the location of the respective prayer centres.

Given the importance of religion in today's society, the mass media cannot elude religious content. Moreover, let us recall that one of the founding principles of public media in Europe was indeed the express obligation to address diversity in order to provide plural content. The regulations in question talk explicitly about highlighting the richness of societies, pointing out linguistic, ethnic, aesthetic, and spiritual aspects. The mass media have to contribute to pluralism, diversity, and democratic expression (Karppinen 2013; Budarick 2019). However, our research does not focus exclusively on the issue of pluralism, but also delves into the treatment of interreligious dialogue in broadcasts by the CCMA. Taking into account the mass media's potential contribution to social cohesion through the dissemination of values and knowledge, we chose to carry out a study that went beyond the analysis of religious pluralism and delved into the study of audiovisual narratives that set up more than one belief for dialogue.

Tackling interreligious encounters in today's society is no easy task for the media. On the one hand, religious phenomena must be understood and interpreted by taking into account the socio-cultural context in which they occur, which is increasingly complex due to its diversity (Tamayo 2009; Estrada 2001). In intercultural meetings, the question of religion tends to be a source of conflict (Huertas-Bailén 2018; Lobera et al. 2017). On the other hand, the mass media, when it comes to producing such content, should have to consider that we are living in a global and hyper-connected world, where people and messages circulate on a global scale (Morley 2005; Barker 1999), and that there are intercultural encounters that would have been unimaginable until not so long ago (Bhabha 2013; Gökarıksel and McLarney 2010; Göle 2007; Hannerz 1998; Kymlicka 1996). As a result, the media not only have to provide an account of the reality of their immediate and increasingly complex environment, but also to find ways to narrate the interactions and interconnections that occur in that global environment. It is no longer enough to look at the outside world as something exotic.

The question we are asking here is how public television content is addressing intercultural contact and promoting interreligious dialogue, which are key aspects in the political management of multicultural societies. Following UNESCO's guidelines, we feel that responsible communication must not only be concerned with providing exhaustive and accurate information, but must also contribute to intercultural contact.

Moreover, the actual trends in mass media language do not allow for a proper treatment of this issue either. First, there is an audio-visual media environment characterized by spectacularity, a polarized rhetoric around conflict, and a serious loss of credibility in journalistic institutions (Innerarity and Colomina 2020; Valhondo Crego and Gonzalo 2020; Montagut and Carrillo 2017). Secondly, we have to highlight the vainness of the mass media content. Thomas (2016) states that the media have ended up dethroning religion in modern (secular) societies. They have finished up taking its place: we have now replaced the gods with media celebrities. Hjarvard (2011) and Krüger (2018) go further and describe this process by pointing out that, in addition to a decline in the presence of religious content, there has been an increase in banal content, especially in the field of entertainment.

\section{Methodology}

Our object of study is the media treatment of interreligious dialogue in a public service broadcaster. We carried out a quantitative and qualitative analysis on audio-visual material broadcast between the years 2015 and 2018 by the Corporació Catalana de Mitjans Audiovisuals (CCMA) through its four TV channels, namely, TV3, Canal 33, Canal 3/24, and Club Super 3. We worked on a corpus analysis made up of multi-faith messages: two or more religious options (including atheism) are mentioned in each piece of the sample. 
To bring together the different units of analysis, we used the broadcast search tool available on the Corporation's on-demand online service. Prior to this, we defined key words, and they were entered to locate all multi-religious content. These were the terms finally used in that search:

- Catholic: Catholic Church, Catholic/s/, Bishopric and Pope Francis

- Evangelical: Evangelical church, Evangelicals, Baptism, Baptist/s, Pentecostals, Lutherans, Anglicans

- Muslim: Islam, Islamist, Muslim(s), Mosque, Islamism

- Christian Witnesses of Jah (2): Jehovah, Christian Witnesses of Jah

- Buddhism: Buddhist/s, Buddhism, Buddhist monk

- Orthodox: Orthodox church, Coptic Christians, Orthodox Christians, Orthodox priest, Orthodox

- Hinduism: Hinduism, Hindu religion, Hinduist

- Adventist: Adventist(s), Adventist church

- Mormonism: Mormon/s

- Church of Jesus Christ of Latter-day Saints: Church of Jesus Christ of Latter-day Saints

- $\quad$ Sikhism: Sikh, Sikhism

- Taoism: Taoism, Taoist

- Judaism: Jew/s, Judaism

- Bahaism: Bahá'í Faith, Bahaism

- Atheism: Atheist/s, Atheism, Agnostic

This was no easy task. Firstly, with regard to the search words, as this process unfolded, we detected the need to use all available variable words in gender and number. Secondly, there were terms that did not detect content related to our object of study or that generated very biased lists, so their use was eventually rejected. For example, expressions such as "Easter" or "Christmas" led us mostly to pieces related to leisure, consumption, and holidays, or the term "Buddha" often led us to news events that occurred on an island off the coast of Tarragona (Catalonia) that bears that name.

In addition, many problems were recorded in the cataloguing of the material carried out by the CCMA itself. Although the requirement was that the search word should be present in the title and in the summary of the presentation of the piece (as we considered that this would be a sufficient guarantee of addressing religious content), the material located did not always refer to this subject.

All this forced us to extend the search period. This task, to which we had planned to devote one month, would eventually run from November 2018 to January 2019, both months included. In the first phase, only 25 multi-religious pieces were found and, with the careful refinement of the search words, we finally managed to form a corpus analysis with 41 pieces (See Tables 1-4).

However, in order to obtain this sample, besides the readjustments related to the search words, the broadcasting period of the material to be analysed had to be extended. Originally, and given that the interest was to deal with the most recent media treatment, the objective was to analyse material broadcast only during the year 2018; however, as this did not allow us to achieve an adequate sample of pluri-religious audio-visual material, we had to increase it to four years, thereby covering the years from 2015 to 2018. Of the 41 pieces analysed, 29 were broadcast during 2018 and 12 correspond to the period 2015-2017. 
Table 1. Audio-visual material analysed where the perspective of the Catholic religion predominates.

\begin{tabular}{|c|c|c|c|c|}
\hline Reference & Date of Broadcast & Duration & Original Programme/Genre & Title \\
\hline 91 & $31 / 03 / 2018$ & 00:49:15 & FAQs (TV3)—Infotainment & Can Holy Week be celebrated in a non-denominational state? \\
\hline 93 & $22 / 11 / 2018$ & 00:58:17 & World 324 (TV3)-Information & Churches and power \\
\hline 98 & $30 / 10 / 2016$ & 00:01:03 & TN Vespre (The Evening News show) (TV3)—Information & $\begin{array}{l}\text { Pope Francis travels to Sweden to bring together Catholics and } \\
\text { Lutherans }\end{array}$ \\
\hline 109 & $15 / 11 / 2018$ & 00:27:23 & Els Matins (The Morning Show) (TV3)-Infotainment & Debate on the existence of God with a monk and an agnostic woman \\
\hline 110 & $4 / 11 / 2018$ & 00:02:43 & TN Vespre (The Evening News Show) (TV3)-Information & 4040 agnostics spend the weekend with the monks of Montserrat \\
\hline 111 & $16 / 04 / 2018$ & 00:01:18 & Noticies 3/24 (3/24)-News Information & $\begin{array}{l}\text { The pope comforts a child who is worried that his late father (atheist) } \\
\text { will not be in heaven }\end{array}$ \\
\hline 112 & $21 / 12 / 2018$ & 00:09:43 & When the Martians arrive (TV3)-Infotainment & Christmas: traditions and contradictions \\
\hline 114 & $10 / 06 / 2018$ & 00:04:21 & Signes del temps (Signs of the times) (TV3)-Specialised news & $\begin{array}{l}2260 \text { religious and lay students study at the Catalan Faculty of } \\
\text { Theology }\end{array}$ \\
\hline 11 & $27 / 09 / 2018$ & 00:33:13 & Els matins (The Morning Show) (TV3)-Infotainment & $\begin{array}{l}\text { Who owns the churches? Controversies about ownership of real } \\
\text { estate }\end{array}$ \\
\hline 15 & $21 / 01 / 2018$ & 00:29:25 & Signes del temps (Signs of the times) (TV3) Specialised news & $\begin{array}{l}\text { Interview with Miquel Calsina, rector of seven parishes in Baix } \\
\text { Empordà and media delegate of the bishopric }\end{array}$ \\
\hline 22 & $13 / 03 / 2018$ & 00:20:47 & Els Matins (The Morning Show) (TV3)—Infotainment & The most important events of the five years of Pope Francis' papacy \\
\hline 26 & $20 / 11 / 2018$ & 00:03:20 & Polònia (TV3)—Political Humour-Satire & $\begin{array}{l}\text { The seat of Christ: The Nativity Scene in Barcelona this year leaves } \\
\text { no one unmoved }\end{array}$ \\
\hline
\end{tabular}


Table 2. Audio-visual material analysed where the perspective of the Muslim religion predominates.

\begin{tabular}{|c|c|c|c|c|}
\hline Reference & Date of Broadcast & Duration & Original Programme & Title \\
\hline 94 & $22 / 03 / 2016$ & 00:01:28 & TN Vespre (The Evening News Show) (TV3)-Information & Profile of young western jihadists \\
\hline 100 & 09/05/2018 & 00:01:17 & TN Vespre (The Evening News Show) (TV3)-Information & The Myanmar army admits to having massacred a group of Rohingya \\
\hline 101 & 19/08/2018 & 00:02:04 & TN Migdia (The Midday News Show) (TV3) - Information & Facebook in Myanmar, "decisive" in hate speech against Rohingya \\
\hline 102 & 05/04/2018 & 00:01:44 & TN Migdia (The Midday News Show) (TV3)-Information & Unwanted baby boom in the Rohingya refugee camps \\
\hline 104 & $25 / 08 / 2018$ & 00:02:40 & TN Migdia (The Midday News Show) (TV3)-Information & A year of crisis for the Rohingya \\
\hline 108 & $21 / 02 / 2015$ & 00:06:20 & Tot un món (One entire world) (TV3)—Information & $\begin{array}{l}\text { When Ikram, a Muslim, and Santok, an Indian and a Sikh, fell in love } \\
\text { there was much suffering ... }\end{array}$ \\
\hline 113 & $15 / 02 / 2015$ & 00:01:23 & TN Migdia (The Midday News Show) (TV3) - Information & The controversy in the US over the murder of three Muslims by an atheist \\
\hline 42 & $12 / 12 / 2018$ & 00:01:42 & TN Migdia (The Midday News Show) (TV3)—Information & $\begin{array}{l}\text { The man who attacked and killed three people at the Christmas market is } \\
\text { captured in Strasbourg }\end{array}$ \\
\hline 43 & 10/11/2018 & 00:17:47 & FAQs (TV3)-Infotainment & Dolors Bramon: "Islam is egalitarian, but Muslims aren't." \\
\hline 46 & $18 / 03 / 2018$ & 00:02:01 & TN Migdia (The Midday News Show) (TV3)-Information & The feminist Islam of an imam \\
\hline 50 & $16 / 02 / 2018$ & 00:26:32 & Els Matins (The Morning Show) (TV3)-Infotainment & Six months after the Barcelona and Cambrils terrorist attacks \\
\hline 55 & $15 / 07 / 2018$ & 00:42:02 & 30 Minuts_(TV3)-Information & A mosque next door \\
\hline 57 & 27/04/2018 & 00:01:28 & TN Vespre (The Evening News Show) (TV3)-Information & The mosque on Japan Street is having an inauguration party \\
\hline 58 & $14 / 03 / 2018$ & 00:01:51 & TN Boroughs (TV3)—Information & $\begin{array}{l}\text { The Nou Barris mosque is opening its doors with daily gatherings of } \\
\text { far-right militants }\end{array}$ \\
\hline
\end{tabular}

Table 3. Audio-visual material analysed where the perspective of Judaism predominates.

\begin{tabular}{ccccc}
\hline Reference & Date of Broadcast & Duration & Original Programme & Title \\
\hline 95 & $30 / 01 / 2018$ & $00: 54: 07$ & Sense Ficció (TV3)—Information & $\begin{array}{c}\text { This is the story of Dory Sontheimer, a Catalan pharmacist of German } \\
\text { origin }\end{array}$ \\
\hline 106 & $03 / 04 / 2015$ & $01: 05: 28$ & Sense Ficció (TV3)—Information & God with an accent \\
\hline 107 & $12 / 04 / 2018$ & $00: 06: 47$ & Katalanoski (TV3)—Infotainment & In Washington, we visited the Ohr Kodesh Synagogue to meet Matt Adler \\
\hline 75 & $16 / 05 / 2018$ & $00: 01: 46$ & TN Migdia (The Midday News Show) (TV3)—Information & $\begin{array}{c}\text { Lluís Bassat, publicist and writer, recalls the creation of the State of Israel } \\
\text { as an achievement by Jews the world over } \\
\text { Nenew murder attributed to anti-Semitism in France }\end{array}$ \\
\hline
\end{tabular}


Table 4. Audio-visual material analysed about diverse religious pieces.

\begin{tabular}{ccccc}
\hline Reference & Date of Broadcast & Duration & Original Programme & Title \\
\hline 35 & $1 / 01 / 2017$ & $00: 29: 18$ & Signes del temps (Signs of the times) (TV3)—Specialised news & $\begin{array}{c}\text { Interview with Daniel Rodriguez, president of the Spanish Federation of Evangelical } \\
\text { Religious Organisations, 500 years since the Protestant Reformation }\end{array}$ \\
\hline 38 & $19 / 01 / 2015$ & $00: 19: 28$ & Signes del temps (Signs of the times) (TV3)—Specialised news & 145 years of the Evangelical Church in Gracia (Barcelona) \\
\hline 92 & $21 / 10 / 2018$ & $00: 28: 44$ & Signes del temps (Signs of the times) (TV3)—Specialised news & Youth and religion (conversation with a Sikh, a Muslim and a Buddhist) \\
\hline 103 & $05 / 04 / 2018$ & $00: 01: 12$ & TN Vespre (The Evening News Show) (TV3)—Information & Myanmar creates settlements with Buddhist colonies \\
\hline 65 & $19 / 12 / 2018$ & $00: 12: 05$ & Els Matins (The Morning Show) (TV3)—Infotainment & Augustin Paniker has published a book on Buddhism \\
\hline 82 & $01 / 02 / 2015$ & $00 / 01 / 24$ & TN Vespre (The Evening News Show) (TV3)-Information & Sikh worship centre to open in Lloret \\
\hline 83 & $29 / 11 / 2017$ & $00: 28: 56$ & L'ofici de viure-The art of living (TV3)-Infotainment & Learning to meditate \\
\hline 87 & $19 / 02 / 2015$ & $00: 26: 54$ & Els Matins (The Morning Show) (TV3)—Infotainment & The Chinese community in Catalonia \\
\hline 89 & $07 / 01 / 2017$ & $00: 06: 19$ & Tot un món—-(One entire world) (TV3)-Information & At the border \\
\hline 90 & $25 / 05 / 2015$ & $00: 30: 08$ & Tria 33 (Canal 33)-Infotainment & In-depth interview with Michel Houellebecq \\
\hline
\end{tabular}


Each sample unit was assigned a reference number and a range of information was collected on each unit. The first segment contained identifying data: (a) title under which the channel presented the piece; (b) duration (with the format 00:00:00); (c) original programme under which it was broadcast or programme to which it corresponds in its entirety; and (d) original broadcast date (with the format 00:00:00). A second segment was aimed at detecting information to be analysed in a quantitative way: (a) religion/s being discussed; (b) appearance of the option for non-believers; (c) television genre; (d) territorial location of the subject (Catalonia, outside Catalonia, and hybridisation); and (e) time location (timeless, current, historical). Finally, a third segment was aimed at carrying out qualitative analysis: (a) presence and characteristics of testimonies (number and profile); (b) subject matter addressed; (c) identification and assessment of explicit references to interreligious dialogue; and (d) identification and assessment of explicit references to interreligious conflicts or problems deriving from coexistence.

\section{Results}

\subsection{General Characteristics of the Pluri-Religious Audiovisual Pieces Analysed}

The pieces in which only two religious beliefs are talked about predominate. Most of them correspond to this characteristic (75.6\%: 31 pieces). The rest can be classified into two groups: $14.6 \%$ (6 pieces) deal with 3 religions and $9.8 \%$ (4) with a larger number.

If we examine which religions appear together most often, it is diversity that predominates. We do not find any one predominant combination. The most frequently repeated combination is Islam-Catholicism, but this appears in only 6 of the 41 pieces analysed (14.6\%). Next, the treatment of the non-believer option in relation to the Catholic religion (12.2\%: 5 pieces) and Islam in relation to Buddhism with the same percentage of presence (12.2\%: 5 pieces) stand out. Regarding this last type of content, we should bear in mind that its noticeable presence is due to something circumstantial. It is, to a great extent, the effect of the journalistic follow-up of a single issue: the attacks of the Myanmar army on the Rohingya (Muslim minority) in 2018.

In this attempt to explain those more common combinations, we can add one more, the joint coverage of the Catholic and the Evangelical, although its presence corresponds to only $7.3 \%$ of the sample, namely 3 pieces. The rest, 22 pieces $(53.7 \%)$, respond to specific and very varied combinations; although it is also worth clarifying that the Catholic religion is present in $63.5 \%$ (26 pieces) of the sample.

When the Jewish religion features in a shared audio-visual piece with one or more other religions, it usually occupies a pivotal place in the development of the discourse. In other words, when Judaism is dealt with in a pluri-religious audiovisual piece, the message usually ends up being constructed from a Jewish perspective. This happens in $71.4 \%$ of the pieces in which it appears (present in 7 pieces and this occurs in 5 cases). Something similar occurs with Islam, which becomes the main focus of the content in $60.8 \%$ of cases (it appears in 23 pieces and this happens in 14 of them). On the other hand, when the Catholic religion engages in dialogue with other religions, it only becomes the focal point in $46.1 \%$ of cases (it appears in 26 pieces and this happens on 12 occasions).

In terms of the genre to which they correspond: 28 pieces (68.3\%) are informative, $12(29.2 \%)$ belong to infotainment, and $1(2.5 \%)$ relates to humour (political satire). This predominance of the informative genre explains why most of the pieces (73.2\%: 30 pieces) refer to current affairs. Issues classified as timeless such as, for example, the difficulties of practising a religion or personal stories related to moving closer to a faith, account for $24.4 \%$ (10 pieces) of the sample and, finally, only $2.4 \%$ cover historical events (specifically, this is 1 piece that deals with the historical ties between Spain and Judaism and is based on a biography).

As regards territorial location, most of them deal with issues from both inside and outside Catalonia (39\%: 16 pieces), but those that focus only on Catalan territory (36.6\%: 15 pieces) and those that explain events that have taken place abroad (24.4\%: 10 pieces) are also noteworthy. In a way, we can say that, from the territorial perspective, the information is balanced. 
Finally, in only 4 of the analysed pieces, a strategy is applied to ensure a balanced presence of the religions dealt with. In these cases, either a dialogue/debate takes place between people who act as spokespersons or representatives of different beliefs and moderated by someone who is concerned about controlling this balance, or the programme is divided by religions into differentiated segments, which can even function independently when corresponding to discourses that are not interrelated and can be interpreted individually.

\subsection{Interreligious Dialogue in Audiovisual Narrative}

In general terms, we can say that interreligious dialogue is clearly and directly mentioned, representing the main focus of the discourse, in just $14.6 \%$ of the sample (6 pieces). In contrast, the predominant discourse is one based exclusively on conflict, which plays a leading role in $44 \%$ of the sample (18 pieces). Finally, in the remaining 41.4\% (17 pieces), both perspectives are reflected.

However, in this section, in which we apply a quantitative and qualitative focus, we are going to deal independently with each belief, including the option of atheism. Our analysis has detected peculiarities that are determined by the religion from which they are spoken; therefore, we have chosen to present the results taking this into account. In particular, we will focus on those options that are cited in at least 10 of the 41 pieces analysed. That is to say, on the Catholic and Muslim religions, covered in 26 and 23 pieces respectively, and on atheism, which appeared in 11 pieces. With this minimal presence required, the aim is to ensure that sufficient material is available to tackle the qualitative perspective.

\subsubsection{Narratives Where the Catholic Religion Is Present}

In the narratives in which the Catholic religion appears (26 pieces), there is a balance between the ones that speak openly of conflict and those that argue in both directions, namely, conflict as well as dialogue. Both represent $42.5 \%$ of the specific sample (with 11 pieces each) for a total of $85 \%$ (22 pieces). Thus, only $15 \%$ (4 pieces) address dialogue directly. The latter 15\% usually coincide with sections of the CCMA's specialised religious programme, entitled Signes del temps (Signs of the times), whose material involves what we have called "friendly journalism". These are messages where a critical perspective is suppressed and where responses loaded with paternalism and traditional clichés abound.

When the messages talk about interreligious dialogue, these ideas appear:

(a) All religions offer a path towards dialogue through spirituality. In the case of the Catholic religion, it is argued that this is evident from God's capacity to forgive. For example, in one of the pieces analysed, the protagonist is a child who tells the Pope about his fear of where his father will be after his death, as the child knows that his father was an atheist. The Pope uses this type of argument in his response.

(b) Activities that encourage intercultural exchange, such as open days or ecumenical choir training, are recommended. There is also the defence of religious tourism and experiential tourism, with, for example, the promotion of visits to historical sites and places or the possibility of spending the night in monasteries.

(c) The importance of religious leaders acting as models of tolerance towards other beliefs. For example, one of the stories is about the Pope's trip to Sweden to join the 500th anniversary of Luther's Reformation.

(d) The need to have a greater knowledge of all religions in order, for example, to be more aware of the historical ties that unite us.

When the pieces deal with conflict, these are the issues that stand out:

(a) From the point of view of an atheistic citizenry, there is some reticence and mistrust towards the behaviour of the Catholic Church. Thus, for example, three of the pieces discuss the difficulty of being an atheist in a country with strong Catholic roots, and in two other pieces analysed, they question the fact that the working calendar is determined by religious celebrations in a secular country like Spain. 
(b) There is criticism from other religions that the Catholic Church holds a privileged position.

(c) Occasionally, some of the pieces refer to internal conflicts, for example divisions of opinion regarding celibacy, the role of women, or reported cases of paedophilia.

\subsubsection{Narratives Where the Muslim Religion Is Present}

In the narratives in which the Muslim religion appears (23 pieces), no one piece deals exclusively with interreligious dialogue. Most narratives focus on conflict (69.5\%: 16 pieces) or combine it with dialogue (30.5\%: 7 pieces).

From a qualitative perspective, it is striking that there are no male imams as attestants or direct sources in these pieces. It is usually women wearing a veil who speak as spokespeople for this religion, and in fact, one of the pieces features a female imam in a Nordic country, which is exceptional and responds above all to the logic of "curious news events" that are typical of media spectacle. The high visibility of the veiled Muslim woman results in an imbalanced dialogue, as they enter into a dialogue with religious leaders as believers. Moreover, according to the analysis carried out, this also leads to the topic of conversation becoming almost exclusively focused on the wearing of the veil in the West.

When the piece unfolds in the form of a dialogue, the following ideas are noted:

(a) The need to organize activities that encourage interaction. However, in the material analysed, only one mention has been made of an organization (AUDIR, which is the Association of Friends of UNESCO for Interreligious and Inter-convictional Dialogue).

(b) The fact that some Catholic priests are open to dialogue and making contact is expressly stated as something positive. This appears in one of the pieces analysed on the occasion of a priest's visit to a newly opened mosque.

(c) The usefulness of emphasising the historical-cultural aspects that bring together the different beliefs is highlighted.

(d) Jihadism should be seen as a problem of society as a whole, and the Muslim community should therefore also be considered as victims of it.

(e) One should take into account the problem of Muslim women, as they are doubly affected, both as women and as Muslims. Specifically, this question appears in three pieces. In the first two, there is a debate on the possibility of the existence of a truly feminist Islam. The first is an interview with Dolors Bramon, a Catalan expert on the Arab world and Islam. In the dialogue she is asked, for example, about what exactly the Koran says about a woman's body. Bramon responds by explaining that the West is obsessively concerned about the veil and she is openly against the use of this garment. Bramon regards Islam as egalitarian, but believes Muslims are not. The second is a news account featuring Sherin Khankan, the woman who leads one of the prayers in a mosque in Copenhagen (Denmark). In the report, Khankan explains that she strives to champion a feminist Islam. The interview is possible thanks to the fact that she has been invited to give a talk in Barcelona. In the last piece, the protagonist is Ikram Ouali, a Muslim woman married to a Sikh. Ikram describes the difficulties she has in interacting with her husband's family, which does not accept interfaith marriages. Ikram Ouali explains that she has just applied for the right of asylum in Catalonia.

The parts that talk about conflict have a particular bearing on the reasons that cause it. These are (a) the racist attitude of far-right political parties and (b) the fact that the public regards all Muslims as terrorists.

In some ways, narratives about conflict in Catalonia tend to clearly regard Muslim believers as victims. They have appeared as targets of racist attitudes and hate speech in news stories about the opening of prayer halls and mosques, or they have been directly accused of being terrorists, although the idea that they have been captured with very effective persuasive strategies is also common. But this state of being a victim also happens in content that takes place abroad, such as in the reports on the Myanmar army's attack on the Rohingya Muslim minority. To describe the situation of these people in 
Myanmar, expressions such as the following are used: "buried alive", "ethnic cleansing", "war crime", or "sexual exploitation".

\subsubsection{Narratives Where Atheism Is Present}

Atheism appears in 11 pieces. Some of the results have already been explained in the section devoted to narratives based on the perspective of the Catholic religion, as with a markedly Eurocentric view, the content of Catalan public television tends to forget the option of atheism outside Europe and, therefore, in relation to religions other than Catholicism.

Thus, in almost all of the specific samples (in 9 of the 11 pieces), it is presented as an option to the Catholic religion. In 6 cases, conflict is explored in depth (the difficulties of being an atheist in a secular country where religion is still present in many important areas). In the remaining 3 cases, the message seems to be one of seeking harmony and talks about the capacity of every Catholic person to forgive, the need to create forums and settings for encounter/dialogue, and also the possibility of studying theology in order to understand the believer better.

The other two pieces talk about atheism versus Islam, and in both cases, conflict is at the core of the discussion. One of the scenes features the French writer Michel Houellebecq, who is interviewed in a cultural programme on the occasion of the publication in Catalan of one of his books. Although the conversation revolves mainly around Islam from the perspective of non-believers, the Catholic religion also ends up making its presence felt. In the speech, Houllebecq speaks in a very provocative way. "Although I speak as a writer and atheist, I admit that being an atheist is very sad", "Islam is stupid", and "Christmas and Ramadan are folkloric customs" are some examples of his phrases. The other piece refers to a murder of Muslims by an atheist.

\section{Discussion}

Religious pluralism is present in Catalan public television, as the sample analysed shows a real concern for covering religious diversity in its programming, which is reflected in the variety of religious beliefs included in the pieces found. Thus, although those that only deal with two beliefs/options are noteworthy, the diversity of combinations predominates. Whilst it is true that the Catholic religion is very much present and, moreover, enjoys the privilege of having its own specialised programme, Signes del temps (Signs of the times), we cannot say that it monopolises as far as the scale of presence is concerned. Furthermore, although it is true that the Catholic religion appears in $63 \%$ of the sample, it only becomes the main focus in fewer than half of the cases (46.1\%).

In relation to the presence of interreligious dialogue, the final conclusion is even less optimistic. In quantitative terms, interreligious dialogue has a very reduced role in the sample analysed, and it is conflict, often in polarized terms, that dominates. If we look at the development of such content in terms of quality, there is also no perceived interest on the part of the CCMA to contribute in this regard. For example, very few pieces deal with more than 2 religions (10 out of 41) and, in these cases, only 4 pieces located are concerned with controlling via the script the balanced representation of the different religions treated in the same piece. Furthermore, it is difficult for the few narratives focused on interreligious dialogue detected to have a positive social impact, because most of them talk about recurring themes (to recover the historical record, to improve religious education in schools, or celebrate open days in religious centres, for example), and that does not help in fostering pathways towards encounters.

However, in order to understand how the CCMA approaches religious content, we need to reflect on the process of mediation from a more general perspective. This perspective is indispensable, since it allows us to observe that this pluralism and this interreligious dialogue is, moreover, strongly shaped by a clear European-Catholic focus, which acts to the detriment of intercultural understanding.

The Euro-Catholic-centric view is reflected in several aspects. In the first place, when criticism appears, it is mostly aimed at other religions. In this regard, it is particularly noteworthy that the question of whether Islam can be feminist is very much present, while, on the other hand, the role of 
women in the Catholic Church is barely addressed, which is an issue that has been raised by different Catholic communities.

Secondly, the image of the non-Catholic believers as a victim predominates, which in a way ends up overstating the idea that other believers are victims of their own religion. In our research, this has been observed in a clear way in relation to the Muslim religion, but it can also be detected in the type of complaints registered from atheists in the content analysed. On the other hand, problems involving the Catholic Church, such as paedophilia or the difficulties in dealing with homosexuality in this context, are barely addressed.

Thirdly, dialogue is often presented as something that is practically only possible through the Catholic religion. It is true that only $15 \%$ of the pieces in which the Catholic religion appears propose interreligious dialogue as a core theme, but we have to take into account that this percentage is zero in the case of the pieces that deal with Islam. Even in a piece on the opening of a Muslim oratory, the visit of a Catholic priest to the site is highlighted, and people in charge of the Muslim centre openly praise his attitude.

Finally, atheism, instead of being presented as just another option, is openly expressed in clear opposition to the Catholic Church and its power. Only two of the 41 pieces analysed talks about atheism as an option before another religion, Islam. Additionally, one is an atypical piece, featuring the writer Michel Houellebecq. In a certain way, it is taken for granted that atheism is absent in Arab or Asian countries, to cite only two examples.

This Euro-Catholic perspective, besides being an obstacle to the establishment of intercultural understanding, also compels us to reflect on the role of the mass media in the perpetuation of traditional cultural values. Moreover, when dealing with historical events, this Eurocentric focus is accompanied by the colonialist perspective. Thus, for example, despite Spain's close relationship with North Africa, the tendency is to render invisible the historical links of Muslim culture with Spain. This is in contrast to the tendency to strengthen the historical links of Judaism with Spain, which seems to be better suited to this Eurocentric view. Moreover, this way of approaching history runs counter to the recurrent media discourse that argues that in order to achieve a cohesive society it is necessary for citizens to know the historical links with others. Thus, in our research, rather than trivialization in content, we have found a contradictory narrative, in which broadcasters themselves do not follow the recommendations that they themselves announce. The increase in intercultural contacts in large cities or the new possibilities of intercultural communication in an increasingly hyper-connected global society do not seem to be sufficient for the media to acquire a critical interpretative view of historical events.

This study has allowed us to detect how Catalan public television continues to shape religious discourse based on the values of the Catholic religion. Although it accommodates pluralism and, with scarce relevance, interreligious dialogue as well, other beliefs are observed, explained, and even judged from the perspective of the Catholic religion. The media analysed positions the Catholic religion in the place from which it is convenient to observe, thus giving it a moral value above the rest and thereby favouring the fact that Catholic values continue to carry an important weight in the social imaginary. The media discourse that emerges on interreligious dialogue ends up placing beliefs in a hierarchical order, with the Catholic Church at the forefront.

Funding: This research was funded by Department of Justice, Generalitat de Catalunya: 2017RELIG00003.

Conflicts of Interest: The author declares no conflict of interest.

\section{References}

Aeschbach, Mirjam, and Dorothea Lüddeckens. 2019. Religion on Twitter: Communalization in event-based hashtag discourses. Online Heidelberg Journal of Religions on the Internet 14: 108-30. [CrossRef]

Barker, Chris. 1999. Television, Globalization and Cultural Identities. Buckingham: Open University Press. 
Bayrakli, Enes, and Farid Hafez, eds. 2016. European Islamophobia Report 2015. Ankara: SETA, Foundation for Political, Economic and Social Research, Available online: https://www.islamophobiaeurope.com/reports/ 2015/en/EIR_2015.pdf (accessed on 22 June 2020).

Berger, Peter Ludwig. 1999. The Desecularization of the World. Resurgent Religion and World Politics. Michigan: Eerdmans Grand Rapids.

Bhabha, Homi K. 2013. Nuevas Minorías, Nuevos Derechos. Notas Sobre Cosmopolitismos Vernáculos. Buenos Aires: Siglo XXI.

Blumler, Jay G. 1993. Televisión e Interés Público. Barcelona: Bosch.

Briones-Gómez, Rafael. 2018. Religiones e inmigración en la España actual. Análisis de los cambios en el campo religioso. Gazeta de Antropología 34: 5. Available online: http://www.gazeta-antropologia.es/?p=5082 (accessed on 22 June 2020).

Budarick, John. 2019. Ethnic Media and Democracy. London: Palgrave Macmillan.

Campbell, Heidi A., and Giulia Evolvi. 2020. Contextualizing current digital religion research on emerging technologies. Human Behavior and Emergung Technologies 2: 5-7. Available online: https://onlinelibrary.wiley. com/doi/full/10.1002/hbe2.149 (accessed on 22 June 2020). [CrossRef]

Couldry, Nick, Sonia Livingstone, and Tim Markham. 2007. Media Consumption and Public Engagement: Beyond the Presumption of Attention. Basingstoke and New York: Palgrave Macmillan.

Cuesta, Ubaldo. 2000. Psicología Social de la Comunicación. Madrid: Cátedra.

Díaz-Campo, Jesús, María-Ángeles Chaparro-Domínguez, and Ruth Rodríguez-Martínez. 2018. Los atentados terroristas de Barcelona y Cambrils en la prensa online. Tratamiento informativo en El periódico, El país y The guardian. El Profesional de la Información 27: 1358-67. Available online: https://recyt.fecyt.es/index.php/ EPI/article/view/epi.2018.nov.18 (accessed on 22 June 2020).

Estrada, Juan Antonio. 2001. Razones y Sinrazones de la Creencia Religiosa. Madrid: Trotta.

Gökarıksel, Banu, and Ellen McLarney. 2010. Muslim women, consume capitalism, an the islamic culture industry. Journal of Middle East Woman's Studies 6: 1-18. Available online: https://muse.jhu.edu/article/394242 (accessed on 22 June 2020).

Göle, Nilufer. 2007. Interpenetraciones. El islam y Europa. Barcelona: Ediciones Bellaterra.

Hannerz, Ulf. 1998. Conexiones Transnacionales. Cultura, Gente, Lugares. Madrid: Cátedra.

Hjarvard, Stig. 2011. The mediatisation of religion: Theorising religion, media and social change. Culture and Religion 12: 119-35. Available online: https:/www.tandfonline.com/doi/abs/10.1080/14755610.2011.579719? journalCode=rcar20 (accessed on 22 June 2020). [CrossRef]

Huertas-Bailén, Amparo. 2002. La Audiencia Investigada. Barcelona: Gedisa.

Huertas-Bailén, Amparo. 2018. Islam and Mass Media Consumption in Post-Migration Contexts among Women from Northern Africa in Catalonia (Spain). Societies 8: 91. Available online: https://www.mdpi.com/20754698/8/3/91\#cite (accessed on 15 July 2020).

Innerarity, Daniel, and Carme Colomina. 2020. Desinformación y poder: La crisis de los intermediarios. Revista CIDOB d'Afers Internacionals 124. Available online: https://www.cidob.org/publicaciones/ serie_de_publicacion/revista_cidob_d_afers_internacionals/desinformacion_y_poder_la_crisis_de_los_ intermediarios (accessed on 22 June 2020). [CrossRef]

Karppinen, Kari. 2013. Rethinking Media Pluralism. New York: Fordham University Press.

Krüger, Oliver. 2018. The 'logic' of mediatization Theory in Religion: A critical consideration of a new paradigm. Marburg Journal of Religion 20: 1-30. Available online: https:/archiv.ub.uni-marburg.de/ep/0004/article/view/ 7699 (accessed on 14 August 2020).

Kymlicka, Will. 1996. Ciudadanía Multicultural. Barcelona: Paidós.

Lobera, Josep, Víctor Arco, and Carlos Giménez. 2017. Toward a multi-ethnic public sphere? Media consumption in highly diverse districts in Spain. International Migration 55: 39-52. Available online: https://onlinelibrary. wiley.com/doi/abs/10.1111/imig.12278 (accessed on 14 August 2020). [CrossRef]

Martín-Barbero, Jesús. 1987. De los Medios a las Mediaciones. México: Gustavo Gili.

Meyer, Birgit. 2012. Mediation and the Genesis of Presence: Towards a Material Approach to Religion. Utrecht: Universiteit Utrecht.

Monod, Jean-Clead. 2015. La Querella de la Secularización. De Hegel a Blumenberg. Buenos Aires: Amorrortu. 
Montagut, Marta, and Nereida Carrillo. 2017. Estrategias de espectacularización en las tertulias políticas televisivas. Caso de la cobertura de las elecciones municipales de Barcelona de 2015. El Profesional de la Información 26: 621-29. Available online: https://ddd.uab.cat/record/225053 (accessed on 22 June 2020). [CrossRef]

Morgan, David. 2011. Mediation or Mediatisation: The History of Media in the Study of Religion. Culture and Religion: An Interdisciplinary Journal 12: 137-52. Available online: https://www.tandfonline.com/doi/abs/10. 1080/14755610.2011.579716 (accessed on 22 June 2020). [CrossRef]

Morley, David. 2005. Pertenencias. Lugar, espacio e identidad en un mundo mediatizado. In Pensar este Tiempo. Espacios, Afectos, Pertenencias. Edited by Arfuch Leonor. Buenos Aires: Paidós, pp. 129-68.

Tamayo, Juan José. 2009. Islam. Cultura, Religión y Política. Madrid: Editorial Trotta.

Thomas, Günter. 2016. The mediatization of religion-As tempatation, seduction, and illusion. Media Culture $\mathcal{E}$ Society 38: 37-47. Available online: https://journals.sagepub.com/doi/abs/10.1177/0163443715615659 (accessed on 22 June 2020).

Trias, Eugeni. 1997. Pensar la Religión. Barcelona: Destino.

Trujillo, Tamer Al Najjar, and Alex Iván Arévalo-Salinas. 2019. La cobertura periodística dels atemptats de Barcelona i Cambrils en "Eldiario.es": Anàlisi del tractament informatiu de l'islam. Anàlisi Quaderns de Comunicació i Cultura 60: 81-96. Available online: https://ddd.uab.cat/pub/analisi/analisi_a2019n60/analisi_ a2019n60p81.pdf (accessed on 22 June 2020).

Valhondo Crego, José Luis, and Salomé Berrocal Gonzalo. 2020. Desregulación y soberanía del público en la televisión española: El infoentretenimiento como alternativa al modelo de noticias clásico. Estudios Sobre el Mensaje Periodístico 26: 851-63. Available online: https://revistas.ucm.es/index.php/ESMP/article/view/67817 (accessed on 22 June 2020). [CrossRef]

Wolton, Dominique. 1999. Sobre la Comunicación. Madrid: Acento.

(C) 2020 by the author. Licensee MDPI, Basel, Switzerland. This article is an open access article distributed under the terms and conditions of the Creative Commons Attribution (CC BY) license (http://creativecommons.org/licenses/by/4.0/). 